\title{
SOBRE LOS CONCEPTOS DE CLANDESTINIDAD Y AUTOMARGINACIÓN EN LA LITERATURA DE LA ILUSTRACIÓN ESPAÑOLA
}

José PALlaRÉs MORENO

UNED (Centro Asociado de Cádiz)

El III Encuentro «De la Ilustración al Romanticismo», que, con el lema de Ideas y movimientos clandestinos, se celebró en Cádiz en abril de 1987, sirvió para centrar no pocos aspectos de los conceptos que ahora nos ocupan. En sus conferencias de apertura y clausura, los profesores Bloch ${ }^{1}$ y Caso $^{2}$ señalaron las notas que nos pueden servir para caracterizar la literatura clandestina en sentido estricto y lo que 0 . Bloch denominó clandestinidad de expresión, esto es la transmisión camuflada de ideas prohibidas, incluso en obras publicadas. Es por otra parte conocida la frecuencia con que nuestros ilustrados aluden al hecho de que escriben más de lo que publican y la importancia que poseen los escritos (correspondencia, diarios, etc.) no redactados con una voluntad inmediata de publicación ${ }^{3}$.

1 BLOCH, OLIVIER: «Matérialisme et clandestinite: tradition, écriture, lecture», en De la llustración al Romanticismo. III Encuentro: Ideas y movimientos clandestinos. Cádiz, Universidad de Cádiz, 1988, pp. 13-26.

2 Caso González, José M.: «Un caso atípico de literatura clandestina: el periódico El Censor», Ibidem, pp. 339-361.

3 De estos aspectos se ha ocupado en varias ocasiones Iris M.' ZaVALA. V. como interesantes botones de muestra sus artículos: «Viaje a la cara oculta del Setecientos»,NRFH, XXXIII, 1984, 
Ahora bien, si todos estos textos los analizamos dentro del marco de lo clandestino, los límites tienden a ampliarse de manera inabarcable. Precisión a los mismos intentó poner en su comunicación Juan A. Ríos Carratalá, quien contrapone el modelo del escritor clandestino al del hombre de bien, probablemente el modelo más elaborado del ilustrado. Tras señalar que el hombre de bien puede, a pesar suyo, convertirse en un clandestino al verse excluido por una colectividad que no comparte sus principios de tolerancia, Ríos Carratalá marca la diferencia entre el clandestino propiamente dicho y el hombre de bien que ve reducidas sus posibilidades de actuación y de incidencia en la sociedad: «El clandestino, el que asume conscientemente todas las consecuencias de esta situación, no busca el perfeccionamiento de un modelo social, económico, político, cultural..., que de hecho se niega a reconocerle, sino el alumbramiento de un nuevo modelo donde él tenga su propio y legítimo puesto» ${ }^{4}$. El hombre de bien en cambio sólo pretende mejorar la realidad a la que pertenece mediante el perfeccionamiento de sus elementos. La moderación de nuestros ilustrados puede responder a una buena dosis de autocensura, pero sólo podremos hablar de clandestinidad cuando nos encontremos ante discursos concebidos desde el rechazo al sistema vigente y la voluntad de sustitución de éste por otro diferente.

Frente a la crítica popular ${ }^{5}$, la crítica ilustrada adopta la forma de composiciones serias (discursos, tratados, etc.) que intentan captar los problemas en su globalidad y aportar soluciones y que, además, no tienen como objetivo la crítica a personajes concretos. Esta práctica crítica pretendía incidir en la transformación de la sociedad en la línea propuesta por el crítico. En ocasiones este tipo de discursos se ven sometidos a condiciones de clandestinidad, bien porque no se conciben para su publicación (en ocasiones, una modalidad de autocensura), bien porque los mecanismos represivos de la censura la impiden. Ante esto cabe preguntarse -en línea con lo expuesto por Ríos Carratalá - si es adecuado considerar estos discursos como clandestinos. Según Ríos, en tanto no pretenden la subversión del orden establecido, sino tan sólo su mejora, no parece que sea lo adecuado. Cuando esto se plantee sí podremos ha-

pp. 4-33, y «La censura en la semiología del silencio», en De la llustración al Romanticismo, III Encuentro: Ideas y movimientos clandestinos, Cádiz, Universidad de Cádiz, 1988, pp. 267-283.

Son también fundamentales los estudios de EDITH HelmaN: Jovellanos y Goya. Madrid, Taurus, 1970) y el reeditado hace unos años Trasmundo de Goya. Madrid, Alianza, 1983.

4 Ríos Carratalá, Juan A.: "¿Clandestino e ilustrado?", en De la llustración al Romanticismo. III Encuentro: Ideas y movimientos clandestinos, Cádiz, Universidad de Cádiz, 1988, pp. 329-335 (p. 330).

5 Para el análisis de sus rasgos cfr. EGIDo LOPEZ, Teofanes: Opinión pública y oposición al poder en la España del siglo XVIII (1713-1759). Valladolid, Universidad, 1971. 
blar de clandestinidad en sentido estricto. Y es claro que a esta clandestinidad se puede acceder desde la radicalización de las posturas ilustradas, 0 , mejor, desde la constatación de la imposibilidad de incidir sobre la base social de manera radical, esto es, transformándola en profundidad, utilizando para ello los mecanismos legales existentes. Esto se produce cuando algunos ilustrados se decepcionan con la Ilustración y oponen a la misma un liberalismo cada vez más acentuado.

La expresión de este pensamiento no podrá darse lógicamente dentro de los cauces legales del sistema al que se ataca. Se desarrollará pues según modelos más próximos a la crítica popular, pero a diferencia de ésta (cuyo objetivo no era otro que la manipulación de la opinión pública ante temas e intereses puntuales) ${ }^{6}$, el discurso clandestino liberal, a semejanza con el discurso ilustrado, pretenderá configurarse como un análisis globalizador. Es lo que ocurre por ejemplo en Pan y toros, modelo claro de texto redactado desde una clandestinidad conscientemente asumida.

\section{* * *}

Ahora bien, ¿renunciarán estos autores a la utilización de los sistemas legales de expresión de ideas, o, por el contrario, pretenderán utilizarlos para exponer las suyas de forma camuflada? No parece que esta segunda posibilidad sea desechable y a ella se refería Olivier Bloch cuando hablaba de clandestinidad de expresión. Para Ríos, el problema de la clandestinidad es un problema que tiene que ver con la intencionalidad de la crítica y con los destinatarios del discurso.

Por supuesto que esto condiciona los medios de expresión y la disposición de los mismos, pero lo fundamental estriba en la actitud de radical desconfianza en las posibilidades de transformación de las estructuras vigentes, y menos aún si había que basarse en el propio poder. De todas formas quizás el ligar tan férreamente como hace Ríos la condición de clandestinidad con la intencionalidad del discurso, esto es, con su carácter más o menos radical, lleve a un callejón sin salida. Y esto por dos razones:

a) La fuerza que adquieren los mecanismos censores, amparados en el progresivo auge de la intolerancia capitaneado por los sectores privilegiados, lo que hace que no pocos ilustrados se vean forzados, como el propio Ríos reconoce, a asumir una clandestinidad que, sin embargo, no se corresponde con la defensa de ideas propiamente liberales, $\mathrm{y}$, menos aún, revolucionarias. Como

6 V. EGIDO, Te6fanes: Op. cit., pp. 39 y ss. 
han descrito C. López Alonso y A. Elorza, las denuncias del fracaso del reformismo van configurando «una corriente proliberal, anunciadora de los temas y de las posiciones que pasarán a primer plano en 1808 , cuyo soporte social no es una burguesía emergente, sino la lúcida estimación efectuada por una minoría de ilustrados de la contradicción radical con que tropieza la perspectiva reformadora dentro del absolutismo» ${ }^{7}$. Cabe recordar que entre 1781 y 1789 los vehículos de difusión de las nuevas ideas son especialmente los periódicos, pues los escritos más significativos del pensamiento político ilustrado español quedan inéditos (Cartas de Arroyal, Apuntes de Gándara, etc.). Así, las dificultades de publicación hacen que la producción ideológica impresa tenga sólo un valor relativo a la hora de analizar las ideologías ilustradas ${ }^{8}$.

b) La constatación de que entre el pensamiento ilustrado y el pensamiento liberal no hay un corte radical, sino que, por el contrario, lo que existe es un proceso gradual que cada ilustrado o grupo de ilustrados recorrerán con mayor o menor timidez. Como escribe Fontana «no existe esta disyuntiva entre reforma y revolución, porque la revolución surge de la evidencia de que la reforma es inviable, y la reforma sólo llega a producirse cuando la realidad de la revolución en un país, o el temor a su contagio en otros que todavía no la han experimentado, fuerzan a sus clases dirigentes a ceder algo para no perderlo todo»? De forma similar lo explica José Antonio Maravall: «Esto nos lleva a comprobar - afirma - que entre esas dos fases del pensamiento político (se refiere al pensamiento de la Ilustración y al pensamiento de la Revolución) no hay una separación tajante que las haga incompatibles entre sí, sino que, al modo como el movimiento doctrinal de la Revolución surge de las Luces del XVIII, también en España, la apertura a unas concepciones de orientación democrática se ligan con el desenvolvimiento históricamente dado, del despotismo ilustrado. De esta manera, se pasa de una visión autocrática y transpersonalista de la potestad del gobierno político, a una justificación individualista y de base democrática, la cual nace y se desarrolla sobre presupuestos teóricos de la etapa pre-

7 López Alonso, Carmen y Elorza, Antonio: El hierro y el oro. Pensamiento politico en España, siglos XVI-XVIII. Madrid, Historia I6, 1989, p. 161. Cfr. ElorZA, Antonio: «Las ideas polfticas: Ilustración y anti-ilustración», en Historia 16, Extra n. ${ }^{2}$ VIII, diciembre 1978 , pp. 69-86.

8 Sobre la importancia y papel de la censura, cfr. los trabajos de Lucienne DOMERGUE, especialmente su Censure et lumieres dans l'Espagne de Charles III. París, Ed. du CNRS, 1982, y las recientes páginas de Francisco AgulLAR PIÑal: Introducción al siglo XVIII. Barcelona, Júcar, 1991, pp. 118-124.

9 FontanA, Joseph: «Prólogo» a AyMEs, Jean-René, ed.: España y la Revolución francesa. Barcelona, Crítica, 1989, p. XII. 
cedente. Tales cambios hacen posible que por quienes han partido del despotismo ilustrado se acepten y valoren posiciones revolucionarias y que pueda pasarse a éstas fácilmente, por lo menos en síntesis provisionales e inestables, con la herencia del pensamiento monárquico ${ }^{10}$. Ahora bien, constatar la existencia de esa evolución gradual no puede suponer que prescindamos de las diferencias. Gérard Dufour se ha ocupado de marcarlas señalando que si bien tanto los ilustrados como los liberales se definen por su oposición a un enemigo común (los conservadores), lo que hace que ambos movimientos sean indisociables, los liberales serán capaces de independizarse del principio de autoridad, mientras que los ilustrados siguieron apegados al mismo (la fundamentación de la Constitución en la historia podría valer como ejemplo), lo que implicaba la negación de veleidades revolucionarias. Así mientras que el proyecto de la llustración se corresponde con un intento de reformas administrativas, «el liberalismo español abrigaba, desde sus comienzos, la ruptura con el sistema monárquico. Era una consecuencia perfectamente lógica de la noción de pacto social»" ${ }^{11}$.

Pero existen - como decimos- vías de penetración y de desarrollo de la ideología liberal entre los ilustrados españoles ${ }^{12}$. Y cuanto mayor sea la evolución de las actitudes críticas, más fácilmente tendrán nuestros ilustrados que recurrir a fórmulas de expresión clandestinas, pues si bien en determinados temas y en determinadas instituciones ${ }^{13}$ pueden coincidir las corrientes del reformismo aristocrático y del pensamiento burgués, que, además, recurren a vehículos comunes de expresión, las diferencias surgen cuando se tocan temas de fondo, especialmente los que conciernen al privilegio. Cuando esto pasa, la opción será el silencio o la expresión marginal o clandestina.

***

Quizá podamos matizar más lo que decimos introduciendo el concepto de automarginación. Siguiendo el consejo expresado en su ya citada intervención por el Prf. Caso, hemos recurrido para fijar este concepto a diversos dicciona-

10 Maravall, José Antonio: «Estudio preliminar» a CabarRús, Conde de: Cartas sobre los obstáculos que la naturaleza, la opinión y las leyes oponen a la felicidad pública. Madrid, Castellote ed., 1973, pp. 11-55 (pp. 12-13).

11 Dufour, Gérard: «De la Ilustración al Liberalismo», en La llustración Española. Alicante, Diputación Provincial, 1986, pp. 363-383 (p. 381). 1970.

12 V. EloRzA, Antonio: La ideología liberal en la Ilustración española. Madrid, Tecnos,

13 V. López Alonso, Carmen y Elorza, Antonio: Op. cit., pp. 164 y ss. 
rios enciclopédicos y, así, en uno de ellos ${ }^{14}$ encontramos las siguientes acepciones de la palabra marginar: «1) Hacer anotaciones al margen de un escrito. 2) Dejar márgenes al escribir. 3) Dejar a alguien de lado, excluir de una actividad. 4) Apartar de la convivencia social a una persona o grupo humano». De marginado/a da la siguiente definición: «Se dice del individuo que no se ajusta al modelo (étnico, sexual, físico, de conducta) ideológicamente dominante de normalidad y queda, por tanto, situado fuera de los cauces de participación o decisión social».

A la luz de estas definiciones podemos entender la automarginación como algo que circunscribimos exclusivamente al campo de la conducta (de la actividad pública) de orden intelectual, y que se manifiesta en la producción de discursos ideológicos (asociada a veces a la adopción de actuaciones directamente políticas) enfrentados con los considerados «normales» por el poder. Este enfrentamiento ideológico puede responder a diversas causas que, como bien ha explicitado Gonzalo Puente Ojea, configuran tres grandes tipos de discursos ideologicos, atendiendo al nivel de contestación frente a la ideología dominante. Hablaremos así de subideologías, cuando los discursos se limiten a rellenar huecos dentro del sistema ideológico dominante, de contraideologías, cuando denuncien su insinceridad, pero sin romper con él, y de ideologías revolucionarias, cuando cuestionen el horizonte utópico de la época ${ }^{15}$. Estos últimos sobre todo, aunque no exclusivamente, son discursos que suelen quedar situados «fuera de los cauces de participación o decisión social».

Pero cuando hablamos de automarginación estamos indicando también que el discurso marginado lo es por «voluntad» de su autor o autores, que pueden o no asumir también el papel de marginados. Se trata pues de un intento de intervención en la vida social estratégicamente concebido desde fuera de los cauces de participación considerados normales, aunque en ocasiones sus autores procuren también la intervención normalizada.

Uno de los soportes fundamentales sobre los que se asienta la Ilustración es el convencimiento de que todo o, al menos, lo que afecta a las relaciones socio-políticas, debe estar regido por la razón. No es pues de extrañar que la última consecuencia de esa actitud fuese la de cuestionar la propia legitimidad del poder real con el que los intelectuales habían pactado ${ }^{16}$. El Despotismo Ilustra-

14 Se trata del Diccionario enciclopédico Grijalbo, cuya consulta frecuente confirma la justeza de los elogios que le dedicó Jorge Luis Borges.

15 V. PUENTE OJEA, Gonzalo: Ideología e historia. La formación del cristianismo como fenomeno ideolbgico, 2.' ed., Madrid, Siglo XXI, 1976.

16 Cfr. Maravall, José Antonio: «Las tendencias de reforma política en el siglo XVIII español», Revista de Occidente, n. ${ }^{2} 18,1967$, pp. 53-82. 
do se revelaba así como algo inestable y cuando su sistema político impide la aplicación de la Razón a todos los análisis de la realidad, algunos de los cuales aparecen como claramente subversivos, los autores de los mismos procuran escapar de la censura marginando sus propios discursos, esto es, sacándolos fuera de los cauces normales de intervención en la vida social, no válidos para sus objetivos. Para ellos utilizan, como veremos, distintos caminos o procedimientos que procuraremos ejemplificar. Volviendo a las definiciones del Diccionario, los procedimientos serán los siguientes:

1) «Hacer anotaciones al margen de un escrito», esto es, hacer guiños al receptor del mismo de manera que éste entienda no lo que el discurso dice textualmente, sino lo que quiere decir, lo que sugiere. La ironía, el sarcasmo y la parodia serán los procedimientos más adecuados para el logro de este objetivo.

2) «Dejar márgenes al escribir», o, lo que es lo mismo, significar por ausencias: no aludir a algo de tal manera que la omisión sea notoria. La explicitación de la autocensura y, en consecuencia, la denuncia de la existencia de mecanismos censores también tiene que ver con esta actitud.

3) «Dejar a alguien de lado, excluir de una actividad». El caso más claro es el del recurso al anonimato, presente en tantas cartas, discursos, viajes fantásticos, etc., aparecidos en la prensa dieciochesca.

4) «Apartar de la convivencia social a una persona o grupo humano» es algo que se cumple en el caso de los discursos que recurren a la difusión clandestina, ilegal. El ejemplo más claro lo tenemos en los panfletos. Algunos, firmados, implican la marginación también de su autor. Pensemos, por ejemplo, en el Discurso sobre los principios de una Constitución libre de Miguel Rubín de Celis, escrito lógicamente desde el exilio. También determinados momentos de la producción de Blanco-White tienen aquí cabida. El panfleto sin firma permite, sin embargo, a su autor seguir ejerciendo actividades legales, si bien los riesgos que corre son evidentes. Es el caso de Pan $y$ toros.

Sólo en este último caso podemos hablar de clandestinidad en sentido estricto, pues aquí aparece la decisión, fruto de la desconfianza absoluta, de romper radicalmente con el sistema vigente y la estructuración del discurso con un objetivo preciso: la agitación. En relación directa con este objetivo se encuentra la opción por un público normalmente más amplio que el receptor del discurso ilustrado. Ahora se trata de incidir sobre la opinión pública. Este interés por la opinión pública que se desarrolla sobre todo a partir de los años 90 «corresponde a una creciente preocupación por la participación de la comunidad 
en los procesos gubernamentales» ${ }^{17}$. En todos los otros casos podremos hablar de clandestinidad de expresión, puesto que se trata de la transmisión de ideas prohibidas de manera encubierta, pero utilizando procedimientos legales, o de marginación del discurso, cuando se restringe el público receptor y se pretende no la agitación de la colectividad, sino incidir sobre las opiniones o conductas individuales de los receptores concretos, estén éstos o no en el poder (cartas, memoriales, etc.). La prudencia obligará a veces a los autores de estos discursos a utilizar procedimientos clandestinos (falta de firma, utilización de seudónimos, etc.), por si el documento cayera en manos distintas de las de su destinatario.

17 GlendinNing, Nigel: «Cambios en el concepto de la opinión pública a fines del siglo XVIII», NRFH, XXXIII, 1984, pp. 157-164 (p. 160). 